\title{
The Influence of Computer Self Efficacy, Computer Experience and Interface Design to Acceptance of Electronic Banking: Empirical Study of Bank Customers in Bekasi City
}

\author{
Henny Medyawati, Marieta Christiyanti, and Muhammad Yunanto
}

\begin{abstract}
The object of this research is customers on the five major banks in the city of Bekasi namely Bank Mandiri, BCA, BRI, Bank Danamon, and BNI. This study aimed to analyze the implementation of electronic banking (e-banking) with the approach of Technology Acceptance Model (TAM). The research method is a survey method with a descriptive analysis and statistical analysis. The data is processed and analyzed by multiple linear regression statistical models using statistical software. The results of this study indicate that the person's ability to use computers, and interface design does not significantly influence perceived ease of use (PEOU). Experience of computer use, relevance, security and privacy significantly influence the perceived ease of use. Relevance does not significantly influence the perception of its usefulness (PU). Interface design, and perceived ease of use significantly influence the perception of its usefulness. Perceived ease of use significantly influences the attitude of its use. Perception of usefulness does not significantly influence the attitude of its use. Attitude for its use significantly influence the real usage and acceptance of e-banking.
\end{abstract}

Index Terms-e-banking, technology acceptance model, customers.

\section{INTRODUCTION}

Company's survival is largely determined by its ability to compete in the marketplace. Ability to compete requires a strategy that can harness all the power and opportunities, and closing strategic weaknesses and neutralize obstacles faced in business dynamics. All that can be done if management can make decisions based on quality information by way of utilization of the technology applied in the company. One of the efforts made in the application of information technology is the use of electronic banking or the popular terms is E-Banking. E-Banking first appeared in the United States in the mid-1990s, in which financial institutions in the United States to introduce and promote e-banking to provide better banking services [2]. E-banking becomes one of the strategies used by the banking industry to compete. E-banking services provided by banks with the main purpose of providing convenience to customers.

Bekasi city with a population of approximately 2.3 million

Manuscript received October 17, 2011 ; revised October 30, 2011.

H. Medyawati , Gunadarma University, Depok, West Java, Indonesia (e-mail: hennymedya@yahoo.co.id).

M. Christiyanti, Gunadarma University,Depok, Indonesia.

M. Yunanto is with Faculty of Economics Gunadarma University, Depok, Indonesia (e-mail: myunanto@staff.gunadarma.ac.id). people located near the capital city of Jakarta. In the period 2003-2006 economic growth in Bekasi always higher than the Province of West Java, in 2003 the economic growth of Bekasi City and increased by 5.25 percent in 2004 to 5.38 percent, then grow high enough up to 6.07 percent in 2006. The measurement to determine how the implementation of e-banking in Bekasi City can be done using information technology adoption or known by the TAM approach. TAM was first introduced by Davis in 1989. TAM describes the relationship between the variables perceived usefulness and perceived easy-of-use, with a variable attitude, intention to use and usage behavior [8], [5]. In the context of research in TAM, perceived usefulness and perceived easy-of-use also called confidence (beliefs) [1], [8]. During this time, the research using TAM is more focused on beliefs with some outcomes such as attitude and usage, i.e, Venkatesh and Brown [9]; Straub, Limayem, \& Karahanna [8]. In this study, the model will include external variables that include variables of individual differences and system characteristic. The two variables used in the individual differences is computer self-efficacy and computer experience, while the variables that will be used for the system characteristic are variable relevance, security and privacy and screen design.

TAM was adapted from the Theory of Reasoned Action (TRA) (Fishbein \& Ajzen, 1975) in [6] by substituting the determinants of attitude with a set of sets consisting of two variables, namely perceived usefulness and perceived ease of use. Although both models (TRA and TAM) is able to predict the interests and usage of information technology with the satisfying, TAM are known to be simple and easy to use yet more powerful in modeling the determinants of user acceptance of computer technology [6]. Another researcher proposed that the relevance of e-banking will enhance our customers' needs perception of usefulness[4].

The problem statement for this research are:

1. Are individual differences influence perceived ease of use (PEOU)?

2. Are the system characteristics influence perceived ease of use (PEOU) and perceived usefulness (PU)?

3. Whether perceived ease of use (PEOU) affects perceived usefulness (PU)?

4. Whether perceived ease of use (PEOU) influences the attitude of the user (ATU)?

5. Does the perception of usefulness (PU) affect the attitude of the user (ATU)?

6. What is the attitude of its use (ATU) affect the acceptance of e-banking (ACC)? 


\section{DATA AND RESEARCH MODEL}

The variables used in this study consisted of eight independent variables and one dependent variable. The independent variables are the computer self-efficacy (CSE), computer experience (CE), relevance (R), security and privacy (SP), screen design (SD), perceived ease of use (PEOU), perceived usefulness (PU), and attitude toward using (ATU) while the dependent variable is the acceptance of e-banking (ACC). Measurement of variables question on computer self-efficacy (CSE), computer experience (CE), relevance (R), security and privacy (SP), screen design (SD), perceived ease of use (PEOU), perceived usefulness (PU), and attitude toward using (ATU) uses Likert scale with 4 choice questions, which is a number 1 for strongly disagree option, the option number 2 for disagree, number 3 for the choice to agree, and number 4 for the choice could not agree more. As for the variable acceptance of e-banking (ACC) uses 7 digit range scale ranging from 1 for strongly disagree option to number 7 for strongly agree choice.

\section{A. Research Model}

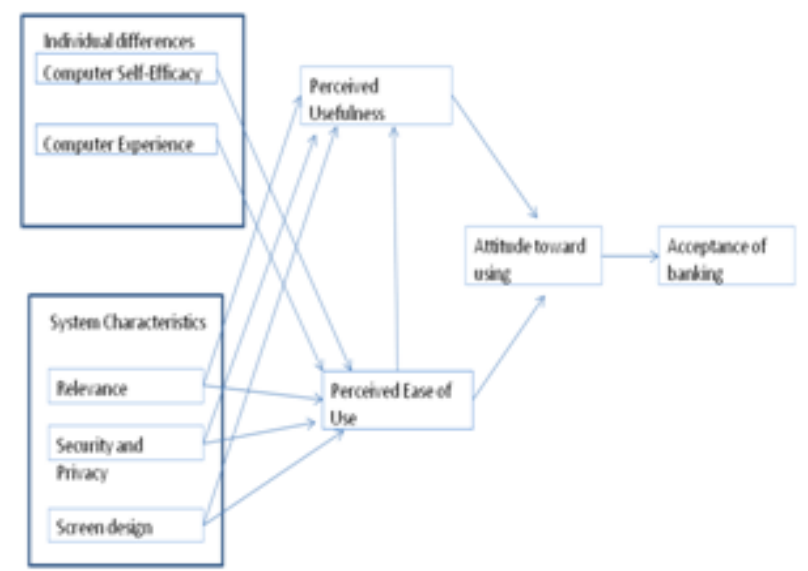

Fig. 1.Research Model

(Source: Hong et.al.2002 in Nugroho and Didi Achjari)

\section{B. Research Hypothesis}

From the model above, the hypothesis that can be constructed are:

H1a: The ability of anyone in using computer (Computer Self-Efficacy or CSE) will affect the perception of ease of use (PEOU)

H1b: Experience over the use of computers (Computer Experience or CE) will affect perceived easy-of-use (PEOU)

$\mathrm{H} 2 \mathrm{a}$ : Relevant (Relevance or R) will affect perceived easy-of-use (PEOU)

H2b : Relevant (Relevance or R) will affect the perception of its usefulness or perceived usefulness (PU)

H2c : Security and Confidentiality (Security and Privacy, or SP) will affect perceived easy-of-use (PEOU)

H2d: Security and Confidentiality (Security and Privacy, or SP) will affect the perception of its usefulness or perceived usefulness (PU)

H2e: Design Interface (Screen Design or SD) will affect the perception of ease of use or perceived easy-of-use (PEOU)

H2f : Design Interface (Screen Design or SD) will affect the perception of its usefulness (PU)

H3 : Perceived ease of use (PEOU) will affect the perception of its usefulness (PU)

H4 : Perceived ease of use (PEOU) will affect the attitude of the user or the Attitude Toward Using (ATU)

H5 : Perception of usefulness or perceived usefulness (PU) will affect the attitude of the user (ATU)

H6 : The attitude of the user (ATU) will affect the acceptance of e-banking

\section{RESUlT AND DisCUSSION}

The data of this research were collected by means of a questionnaire distribute to 500 individual bank customers in Bekasi City. After a follow-up round a total of 470 questionnaires were received, of which 446 were used in the data analysis. The response rate was 89.2 percent. The respondent overview could be explained below.

\section{Gender of the Respondents}

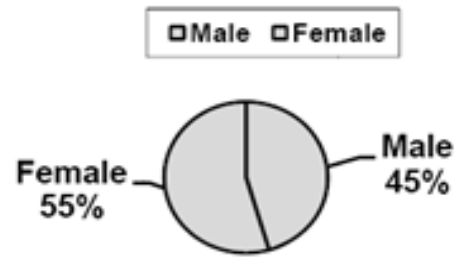

Fig. 2 Gender of the respondents

Fig.2 above show that the number of female respondent are much more than the male. This condition is a coincidence because the sampling method applied in this research is accidental sampling.

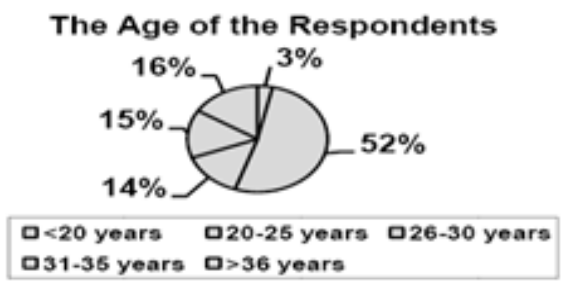

Fig. 3. The Age of the Respondents

Respondents in this research majority are come from the age between $20-25$ years that is about $52 \%$, below 20 years is about 3\%. Another result is the age between 26-30 is about $14 \%, 31-35$ years is about $15 \%$ and above 36 years is about $16 \%$.

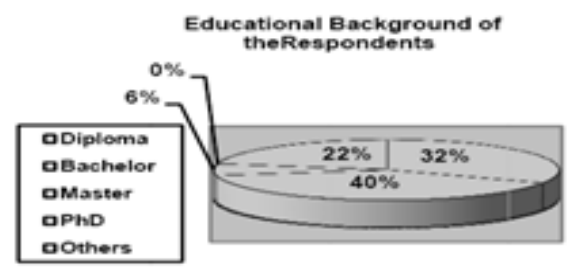

Fig. 4 the Educational Background of the Respondents

From the Fig. 4 above, we can see that the majority of the respondents in this research are come from the Bachelor degree, that is about $40 \%$, then diploma degree is about $32 \%$, others background which could be graduate from high school or junior high school is about $22 \%$. There is no $\mathrm{PhD}$ 
background in this research.

\section{A. Factor Analysis}

Based on the results of factor analysis, it was found that all the variables used in this study, namely variable CSE, CE, R, SP, SD, PEOU, PU, ATU, and the ACC has a value of KMO MSA (Kaiser Meyer Olkin Measure of Sampling Adequacy) for more than 0.5 and significantly below 0.05, all factor loading was above the cutoff point of 0.55 , and on each of the questions in each variable grouped in one factor [7], which declared all these variables can be analyzed further.

After factor analysis then validity and reliability test conducted. The result of the 8 independents variables (CSE, CE, Relevance, Security and Privacy, Screen Design, PEOU, PU and ATU) test can be seen below.

TABLE I: THE VALIDITY AND RELIABILITY ANALYSIS OF COMPUTER SELF EFFICACY

\begin{tabular}{|l|l|l|l|}
\hline & Questions & CITC & $\begin{array}{l}\text { Cronbach's } \\
\text { Alpha }\end{array}$ \\
\hline CSE1 & You feel easy using e-banking & 0,488 & \\
\hline CSE2 & You need special training & 0,574 & 0.720 \\
\hline CSE3 & $\begin{array}{l}\text { You are an expert to use } \\
\text { e-banking }\end{array}$ & 0,593 & \\
\hline
\end{tabular}

Note: CITC abbreviation from Corrected Item-Total Correlation

TABLE II: THE VALIDITY AND RELIABILITY TEST OF COMPUTER EXPERIENCE

\begin{tabular}{|l|l|c|l|}
\hline & Questions & CITC & $\begin{array}{l}\text { Cronbach's } \\
\text { Alpha }\end{array}$ \\
\hline CE1 & $\begin{array}{l}\text { With your experience, it is } \\
\text { easy to use e-banking }\end{array}$ & 0,517 & \\
\hline CE2 & $\begin{array}{l}\text { With your experience, you } \\
\text { can help other people about } \\
\text { e-banking }\end{array}$ & 0,679 & 0.760 \\
\hline CE3 & $\begin{array}{l}\text { You already have many } \\
\text { experience with e-banking }\end{array}$ & 0,600 & \\
\hline
\end{tabular}

TABLE III: THE VALIDITY AND RELIABILITY TEST OF RELEVANCE

\begin{tabular}{|l|l|c|l|}
\hline & Questions & CITC & $\begin{array}{l}\text { Cronbach 's } \\
\text { Alpha }\end{array}$ \\
\hline R1 & $\begin{array}{l}\text { The information is } \\
\text { relevance }\end{array}$ & 0.374 & \\
\hline R2 & $\begin{array}{l}\text { Bank never make mistakes } \\
\text { when you make a } \\
\text { transaction }\end{array}$ & 0.438 & 0.610 \\
\hline $\begin{array}{l}\text { The information available } \\
\text { is relevance to protect } \\
\text { customers transaction }\end{array}$ & 0,513 & \\
\hline
\end{tabular}

TABLE IV: THE VALIDITY AND RELIABILITY TEST OF SECURITY AND

\begin{tabular}{|c|c|c|c|}
\hline \multicolumn{4}{|c|}{ PRIVACY } \\
\hline & Questions & CITC & $\begin{array}{l}\text { Cronbach 's } \\
\text { Alpha }\end{array}$ \\
\hline SP1 & $\begin{array}{l}\text { You trust the money } \\
\text { transfer system with } \\
\text { e-banking }\end{array}$ & 0.645 & \\
\hline SP2 & $\begin{array}{l}\text { You trust the security } \\
\text { of e-banking }\end{array}$ & 0.492 & \\
\hline SP3 & $\begin{array}{l}\text { The bank has enough } \\
\text { control to protect data } \\
\text { and the money }\end{array}$ & 0.452 & 0.756 \\
\hline SP4 & $\begin{array}{l}\text { You trust when giving } \\
\text { personal information } \\
\text { through e-banking }\end{array}$ & 0.533 & \\
\hline SP5 & $\begin{array}{l}\text { The bank protect the } \\
\text { personal information a }\end{array}$ & 0.522 & \\
\hline
\end{tabular}

TABLE V: THE VALIDITY AND RELIABILITY TEST OF SCREEN DESIGN

\begin{tabular}{|l|l|c|l|}
\hline & Questions & CITC & $\begin{array}{l}\text { Cronbach's } \\
\text { Alpha }\end{array}$ \\
\hline SD1 & $\begin{array}{l}\text { Design screen is } \\
\text { attractive and unique }\end{array}$ & 0,387 & \\
\hline SD2 & $\begin{array}{l}\text { The structure of the menu } \\
\text { is good }\end{array}$ & 0,506 & \\
\hline SD3 & $\begin{array}{l}\text { The size of the word is } \\
\text { appropriate }\end{array}$ & 0,577 & 0.745 \\
\hline SD4 & $\begin{array}{l}\text { The bank's logo, call } \\
\text { center and the help menu } \\
\text { are available }\end{array}$ & 0,526 & \\
\hline SD5 & $\begin{array}{l}\text { All the symbols, } \\
\text { language and menus are } \\
\text { easy to understand }\end{array}$ & 0,558 & \\
\hline
\end{tabular}

From those tables above, all the score for CITC are positive, this can be conclude that all indicator can be use for further analysis.

TABLE VI: The VALidity AND Reliability Test of PeRCEIVED EAsE OF USE (PEOU)

\begin{tabular}{|l|l|l|l|}
\hline & Questions & CITC & $\begin{array}{l}\text { Cronbach's } \\
\text { Alpha }\end{array}$ \\
\hline PEOU1 & $\begin{array}{l}\text { The easiness of } \\
\text { e-banking registration }\end{array}$ & 0,516 & \\
\hline PEOU2 & $\begin{array}{l}\text { Using e-banking is } \\
\text { very easy for me }\end{array}$ & 0,650 & \\
\hline PEOU3 & $\begin{array}{l}\text { You find an easiness to } \\
\text { do whatever you want } \\
\text { through e-banking }\end{array}$ & 0,494 & 0.804 \\
\hline PEOU4 & $\begin{array}{l}\text { Your understanding } \\
\text { about e-banking is very } \\
\text { clear }\end{array}$ & 0,679 & \\
\hline PEOU5 & $\begin{array}{l}\text { With e-banking, you } \\
\text { don't have to work so } \\
\text { very hard but works } \\
\text { smart }\end{array}$ & 0,493 & \\
\hline PEOU6 & $\begin{array}{l}\text { e-banking makes you } \\
\text { easy to find relevance } \\
\text { information }\end{array}$ & 0,557 & \\
\hline
\end{tabular}

TABLE VII: THE VALIDITY AND RELIABILITY TEST OF PERCEIVED USEFULNESS

\begin{tabular}{|l|l|c|l|}
\hline & Questions & CITC & $\begin{array}{l}\text { Cronbach's } \\
\text { Alpha }\end{array}$ \\
\hline PU1 & $\begin{array}{l}\text { The use of e-banking } \\
\text { fasten your works }\end{array}$ & 0,598 & \\
\hline PU2 & $\begin{array}{l}\text { e-banking makes you } \\
\text { access the much more } \\
\text { information, fast and } \\
\text { accurate }\end{array}$ & 0,721 & \\
\hline PU3 & $\begin{array}{l}\text { e-banking makes your } \\
\text { jobs effectives }\end{array}$ & 0,662 & 0.834 \\
\hline PU4 & $\begin{array}{l}\text { You use e-banking to } \\
\text { process other people } \\
\text { transaction }\end{array}$ & 0,630 & \\
\hline PU5 & $\begin{array}{l}\text { e-banking is very } \\
\text { helpful in every } \\
\text { activity }\end{array}$ & 0,533 & \\
\hline PU6 & $\begin{array}{l}\text { You will use e-banking } \\
\text { in every activity }\end{array}$ & 0,516 & \\
\hline
\end{tabular}

Table I until Table VIII are validity and reliability test for independence variables. The next step is validity and reliability for the dependence variable namely acceptance of E-banking. The result for the test can be seen below.

From the test validity and reliability in Table I - Table IX, could be seen that all CSE indicators, CE indicators, $\mathrm{R}$ indicators, SP indicators, SD indicators, PEOU indicators, 
PU indicators, and ATU indicators have Cronbach's Alpha value of more than 0.60. From the ACC indicators consisting of ACC1, ACC2, ACC3, ACC4, ACC5, and ACC6, only the ACC2, ACC3, ACC5, and ACC6 are valid.

TABLE VIII: THE VALIDITY AND RELIABILITY TEST OF ATITUTED TOWARD USING (ATU)

\begin{tabular}{|c|c|c|c|}
\hline & Questions & CITC & $\begin{array}{l}\text { Cronbach 's } \\
\text { Alpha }\end{array}$ \\
\hline ATU1 & $\begin{array}{l}\text { You will use e-banking } \\
\text { in every activity to find } \\
\text { relevance information } \\
\text { to your job }\end{array}$ & 0,630 & \\
\hline ATU2 & $\begin{array}{l}\text { You will learn more } \\
\text { about the development } \\
\text { of e-banking }\end{array}$ & 0,533 & \\
\hline ATU3 & $\begin{array}{l}\text { Using e-banking is a } \\
\text { wise choice to you }\end{array}$ & 0,564 & 0.786 \\
\hline ATU4 & $\begin{array}{l}\text { If you have problem, } \\
\text { then you will actively } \\
\text { connected to the call } \\
\text { center }\end{array}$ & 0,463 & \\
\hline ATU5 & $\begin{array}{l}\text { You will tell your } \\
\text { friend to use e-banking }\end{array}$ & 0,650 & \\
\hline
\end{tabular}

TABLE IX: THE VALIDITY AND RELIABILITY TEST OF ACCEPTANCE OF E-BANKING

\begin{tabular}{|c|c|c|c|}
\hline & Questions & CITC & $\begin{array}{l}\text { Cronbach's } \\
\text { Alpha }\end{array}$ \\
\hline ACC2 & $\begin{array}{l}\text { Frequency number } \\
\text { using e-banking in } \\
\text { one week }\end{array}$ & 0,563 & \\
\hline ACC3 & $\begin{array}{l}\text { The frequency of } \\
\text { dependence to } \\
\text { vendor or technical } \\
\text { support }\end{array}$ & 0,584 & 0.701 \\
\hline ACC5 & $\begin{array}{l}\text { You always use } \\
\text { e-banking to find } \\
\text { related information } \\
\text { to your activities }\end{array}$ & 0,463 & \\
\hline ACC6 & $\begin{array}{l}\text { You will learn about } \\
\text { the e-banking } \\
\text { development }\end{array}$ & 0,381 & \\
\hline
\end{tabular}

\section{B. Hypothesis Analysis}

The results for hypothesis 1a states that a person's ability in using computers (computers self-efficacy or CSE) does not significantly influence the perception of ease of use or (PEOU). This proves that a person's ability in using computers is not always has a positive confidence against the ease of use. There are still other factors beyond the capability of a person in using computers, such as the existence of several applications or specific programs. Anyone maybe have the ability to use computers but he do not have desire use e-banking and also the factor of lack of ability in using other smart electronic devices such as mobile phones, ATM machines. The use of e-banking is not just limited to the use of computers, it is clear that people who have the ability in using the computer not always influence the ease of use of e-banking. This result is in line with Nugroho and Achjari [6], but different from Wijayanti [11] that there is significant relationship between computer self efficacy and perceived usefullness of internet banking. The result support Goh [3], that if the technology infrastructure that supports are available, easily and quickly, then the e-banking applications are becoming more and easy to use.
Result for hypothesis 1b, proves the existence of significant influence of experience on the use of computers (Computer Experience or CE) on the perception of ease of use or Perceived easy-of-use (PEOU). This proves that the customer will evaluate e-banking easy to use if they have experience of computer use (PEOU). The experience on the use of computers owned by the customer, will make customers more easily in use e-banking. The longer the customer experience in using computers, it is increasingly easy for customers to use e-banking. Although the use of e-banking is not only use the computer, at least the customers already know how to use e-banking through the experience. In other words, customers who have experience on the use of computers will be easier in the use of e-banking, compared with customers who do not have experience on the use of computer. This result is the same as Yuadi[13] , that abilities and skills (including the experience of the use of computers) have an influence on perceived ease of use.

The conclusion for hypothesis 2a, show that there is significant relationship between the relevant (Relevance or $\mathrm{R}$ ) on the perception of ease of use (PEOU). This indicates that if the systems relevant, the information become relevant will make effect on ease of use of e-banking. By producing relevant information, the customers feel ease of using e-banking. The irrelevant information, will make the bank customers complain, which makes the use of e-banking become not easy. This condition will be complicated and spend more time-consuming job, customer have come to the bank or contact the service center to lodge a complaint. This result support Yao [12] that users tend to search for relevant documents handy. When an information technology contains a large amount of relevant information it will be easier for customers to find desired information. This result is different from Wijaya and Fahmy Radhi [10] that relevance variable show a weak relevant to perceived easy of use.

For hypothesis 2b, this study shows that the relevant variables or Relevance (R) has no significant effect on perceptions of usefulness (PU). This may be due once the occurrence of errors such as information generated in the balance information which is if the information not relevant to the transaction, customers will feel aggrieved.

For hypothesis 2c, this study shows that the variable Security and Confidentiality (SP) has a significant effect on perceived ease of use (PEOU). This shows that the level of high security and confidentiality will make customers feel secure in the use of e-banking. If the safe condition is not met, then the customer will move on to other banks. A relatively frequent problem is the balance that is not appropriate, require the customer to take care of complaints to the bank.

For hypothesis 2d, the study showed that the variables Security and Confidentiality (SP) had no significant effect on perceptions of usefulness (PU). This indicates that the security and confidentiality in the use of e-banking is still doubted by the customer by the number of cases that occurred lately, such as ATM burglary, and balance discrepancy.

For hypothesis 2e, this study shows that the variable Interface Design (SD) had no significant influence on perceived ease of use or Perceived easy-of-use (PEOU). This shows that the probability of symbols, menus available are not easily understood by customers, or it could be the possibility of the customers who lack sufficient ability to 
understand the feature of e-banking. And may be caused by the customers' concentration whose open other websites at the same time. The customers assume that the display of the e-banking web site is too formal and rigid.

For $2 \mathrm{f}$ hypothesis, the results of this study indicate that variable Interface Design (SD) have a significant influence on the perception of its usefulness (PU). This shows that a good screen design, made with full consideration would provide a useful benefit for customers. With the symbols, such as assistance (help) will help customers find it useful. Screen design that is attractive, capable of making customers comfortably, and easy to understand will make customers to feel the benefits in using e-banking.

For hypothesis 3, the results of this study indicate that the perception variables Perceived ease of use or easy-of-use (PEOU) significantly affects the perception of its usefulness (PU). This proves that the customer will view the benefits of e-banking is also based on ease of use of e-banking. In other words, customers will evaluate e-banking is helpful if they could use e-banking with ease. The ease of use of e-banking for example, not too many procedures to fill some forms, the simple language used can be understood easly by the customer, the customer will easily and quickly be able to feel benefit from the use of e-banking. Some benefits are the effective and efficient in terms of time, effort, and cost, and other benefits that can be perceived by customers.

For hypothesis 4, proves that this study show a significant effect between perceived ease of use of the attitude of the user. This suggests that simply the use of e-banking, making the customer intends to use e-banking. Due to the ease that is felt by customers in the use of e-banking, the customer intends to use e-banking that is expected to provide many benefits for customers. The ease of registration, transactions, transfer funds, and other easyness which will provide benefits to customers so that customers do not have to waste time to visit the bank to transfer the funds. By making a transfer or transaction without having to visit the bank will relatively reduce the level of criminal risk, such as robbery because customers do not need to carry large enough cash in quantities that would cause risk to the customer as happened recently in Indonesia. Usually the customers intend to tell his friends to use e-banking services, for example the transfer of funds, although the transaction can only be made for customers who are both users of e-banking.

For hypothesis 5, the results of this study indicate that the variable perception of its usefulness (PU) is significantly has no effect on the attitude of the user (ATU). This suggests that the possibility of the absence of optimal benefit to be gained by customers, such as the existence of several mistakes made by the bank, or difficulty of transaction process, which only impede the work or activity of the customers. Addtional cost in the form of usage in e-banking transactions are also could make the customers not intended to use e-banking services.

For hypothesis 6 , the results of this study indicate that the variables attitude to its use (ATU) significantly affects the real usage and Acceptance of E-Banking (ACC). This shows that the attitude or intention of its customers on the use of e-banking services cause e-banking service is received and used intensively by the customer. The acceptance and use of concrete made by customers is one kind of form of loyalty that they can give contribution to the bank.

\section{CONCLUSION}

The two variables of individual differences are significantly influence the perceived ease of use of e-banking. The system characteristics which are relevance, security and privacy and security design significantly influence the perception ease of use.

This research have some limitation that are the research conducted only in Bekasi City and the method applied is accidental sampling, so the conclusion cannot represent all the user of e-banking in Indonesia.

For further research, the area for questionnaire distribution should be enlarge and the alternative method of sampling should be applied such as purposive random sampling.

\section{REFERENCES}

[1] Chan, S.C. and Lu, M., 2004. Understanding internet banking adoption and use behaviour: A Hongkong Perspective. Journal of Global Information Management (online journal from proquest),vol.12,Iss.3,pg.21.http://proquest.umi.com/pqdweb?did=64 2433151\&Fmt=4clientId=46969\&RQT=309\&VName+PQD $\quad(2010$, 11 April)

[2] Agarwal, R., \& Karahanna, E. 2000. Time flies when you're having fun: Cognitive absorption and beliefs about information technology usage. MIS Quarterly, 24(4): 665-694

[3] Goh, H.P. 1995. The Diffusion of internet in Singapore. Academic Exercise, Faculty of Business Administration, National University of Singapore

[4] W. H and J. Y.L. Thong, W.M. Wong, dan K.Y. Tam. (2002). Determinants of user acceptance of digital libraries: an empirical examination of individual differences and system characteristics. Journal of Management Information Systems. Winter 2001-2002, Vol. 18, No. 3, hal. 97-124.

[5] W. H., D’Ambra, J., \& Bhalla, V. 2002. An empirical investigation of the adoption of egoverment in Australian citizens: Some unexpected research findings. The Journal of Computer Information System, 43(1): $15-22$.

[6] Nugroho, Enggar Hestu dan Didi Achjari. 2004. "Faktor-Faktor Penentu Penggunaan World Wide Web sebagai Sarana Pendukung Pendidikan: Studi Empirik Mahasiswa Akuntansi Di Yogyakarta”. Prosiding Seminar Nasional Aplikasi Teknologi Informasi 2004. Yogyakarta: Universitas Gajah Mada.

[7] Sarwono, Jonathan. 2006. Analisis Data Penelitian Menggunakan SPSS. Yogyakarta: Andi

[8] Straub, D., M. Limayem, and E. Krahnna-Evaristo. 1995."Measuring System Usage: Implications for Theory Testing, Management Science, 41:8, 1995, pp. 1328-1342.

[9] Venkatesh, V., \& Brown, S.A. 2001. A longitudinal investigation of personal computers in homes: Adoption determinants and emerging challengers. MIS Quartely, 25(1): 71-102.

[10] Wijaya dan Fahmy Radhi. 2004. "Pengaruh Perbedaan Individual dan Karakteristik Sistem terhadap Penerimaan Penggunaan Teknologi Informasi: Replikasi Model di Bidang E-Job Vacancies”. Jurnal Ekonomi \& Bisnis Indonesia, Vol. 19, No. 3, 2004, 269-281.

[11] Wijayanti, Ratih. 2009. Analisis Technology Acceptance Model (TAM) Terhadap Faktor-faktor yang Mempengaruhi Penerimaan nasabah Terhadap Layanan Internet Banking (Studi Empiris Terhadap Nasabah Bank Di Depok). Depok: Universitas Gunadarma.

[12] Y.Y.Yao, 1995. Measuring retrieval effectiveness based on user preference of documents. Journal of the American Society for Information Science, 46(2): 133-145.

[13] Yuadi, Imam. 2009. “Analisis Technology Acceptance Model terhadap Perpustakaan Digital dengan Structural Equation Modeling”. Departemen Ilmu Informasi dan Perpustakaan. http://palimpsest.fisip.unair.ac.id/images/pdf/imam.pdf

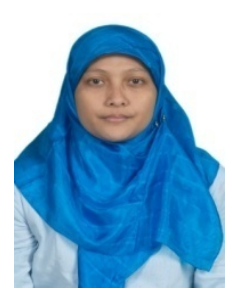

Henny Medyawati, a lecturer in Gunadarma University. Birth in Jakarta, May 18, 1970. Undergraduate Program in Computer Science, Master Program in Management, and completed the Doctoral Program in Economics at Gunadarma University, Depok, Indonesia, on March 5, 2010. Lecturer in Gunadarma University since 1993, teaching subject in Banking Information System, Electronic Banking, and Strategic Management. 
She experience as an instructure in banking system application course, and attended in SAP course in Fundamental and Financial Module at Gunadarma University. As a lecturer, she also served in the head development laboratory at LEPMA in Gunadarma University (Management and Accounting Development Board). After attended the ICEBI 2011, she joint as member of IEDRC.

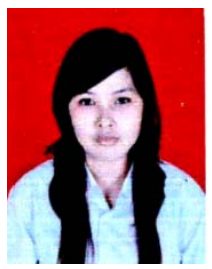

Marieta Christiyanti was undergraduate student in Faculty of Economic, Gunadarma University. Now she is working at Banking and Finance company.

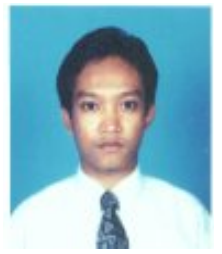

Muhammad Yunanto, a lecturer in Gunadarma University. Birth in Klaten, June 12, 1969. Undergraduate Program in Economics, Master Program in Management, and since 2007 Phd student majoring in Economics in Gunadarma University, Indonesia. Lecturer in Gunadarma University since 1993, teaching subject in Macro Economics, Strategic Management, and Managerial Economics. 